\title{
Vegetation response to millennial- and orbital-scale climate changes in Africa: A view from the Ocean
}

\author{
Ilham Bouimetarhan ${ }^{1}$ \\ Faculté des Sciences appliquées, CUAM, Ibn Zohr University, \\ Agadir, Morocco
}

Lydie Dupont
MARUM - Center for Marine Environmental Sciences, University of Bremen, 28359 Bremen, Germany

Hanane Reddad

L'Ecole Supérieure de Technologie \& Faculté des Lettres et des Sciences Humaines, Sultan Moulay Slimane University, Beni Mellal, Morocco

Asmae Baqloul

Faculté des Sciences, Ibn Zohr University, Agadir, Morocco

Anne-Marie Lézine

Laboratoire d'Océanographie et du Climat, Expérimentation et Approche numérique/IPSL, Sorbonne University, CNRS-IRD-MNHN, Paris, France

ABSTRACT: Pollen from deep-sea sedimentary archives have proved to be a particularly useful tool to provide an integrated regional reconstruction of vegetation and climate (temperature, precipitation, and seasonality) on the adjacent continent throughout the Earth's climate history. In this paper, we have compiled marine pollen records from the African margin in order to assess long-term patterns of vegetation changes during climate cycles. We investigate the changing and complex interplay between African climate and high- and low-latitude forcing at orbital and millennial timescales. More importantly, the study of those records has shown the extent of different biomes during the last ten million years covering the Plio-Miocene, glacial-interglacial cycles, as well as eight Heinrich Stadials, the last deglaciation and the Holocene. In the West African records, arboreal pollen expanded during most interglacials and during the early Holocene. The

\footnotetext{
${ }^{1}$ Other affiliation: MARUM-Center for Marine Environmental Sciences, University of Bremen, 28359 Bremen, Germany
} 
savannah and semi-desert/desert vegetation expanded abruptly during glacials, Heinrich Stadials and the Last Glacial Maximum. Most eastern African pollen records have shown a clear dominance of arboreal taxa throughout all climate cycles except during MIS32 suggesting that a decoupling between eastern and western Africa took place. However, the scarcity of eastern African marine pollen records hampers a reliable comparison between these two sectors.

\subsection{INTRODUCTION}

The distribution and composition of the African vegetation is largely controlled by climate primarily through temperature ranges, radiation and precipitation (e.g. Box 1981; Holdridge 1947; Woodward and Williams 1987; Woodward and McKee 1991). In turn, vegetation can exert an important influence on surface energy fluxes and the hydrological cycle through alteration of the surface albedo and biogeochemical processes, thus affecting climate locally (Denman et al. 2007; Pielke et al. 1998). In Africa, a continent that represents around $20 \%$ of the Earth's surface, and where climate and vegetation data are sparse, our understanding of the vegetation-climate interaction and its consequences on the composition, structure and maintenance of terrestrial ecosystems remains poor. Spanning the equator and encompassing tropical, sub-tropical and temperate climate systems of both hemispheres, Africa provides a unique opportunity to study not only local and regional climate dynamics, but also to investigate and understand vegetationclimate interactions. Thus, allowing feedback effects to be identified on different spatial and temporal scales, and to assess the inter-hemispheric teleconnections in the global climate system. In this paper, we review the current state of knowledge related to African vegetation change over the entire Quaternary (2.6 million years) and older at orbital, millennial and centennial timescales by reviewing a large set of fossil pollen records obtained from marine sediments.

It is well established that the study of fossil pollen contained in sediments facilitates the reconstruction of terrestrial palaeoenvironmental changes through geological times, and constitutes the most widely used quantitative proxy of past vegetation changes (Gajewski 1993; Webb 1986). Pollen grains can be transported over long distances by winds and/or by rivers, and consequently reach the sea floor. Therefore, pollen are present in marine sediments from estuarine to abyssal environments and from the tropics to the Polar Regions. Consequently, their broad occurrence makes them valuable palaeoclimatic and palaeoenvironmental markers especially along the coast of arid environments where terrestrial records are scarce and organic microfossils are badly preserved. Pollen data derived from marine sediments integrate palynological information on large shifts in vegetation over long and continuous periods, with individual sequences of sediments often spanning more than one glacial/interglacial climatic cycle. Pollen records obtained from marine sediments have been shown to be suitable for tracing large-scale climatically related vegetation changes (Hooghiemstra 1988), hydrological variability (Dupont 1999), and for correlations between change on land and in the oceans (Heusser and Shackleton 1979; Hooghiemstra et al. 2006). However, the interpretation of pollen records from marine sediments should be done carefully accounting for several aspects. These include: (i) source and production of pollen grains, because it varies remarkably from one species to another, (ii) transport to the ocean floor and through the water column, (iii) displacement by ocean currents, (iv) sedimentation process, (v) taphonomic processes and early diagenesis, and (vi) fossilization in the sediment (Dupont 1999).

Pollen grains are dispersed over long distances (up to $200 \mathrm{~km}$ ) reflecting the ease with which they can be transported from their source area to the site of sedimentation (Wright 1952). Therefore, the evaluation of transport agents is particularly important in the interpretation of marine pollen records. Aeolian transport of pollen grains predominates in deep-sea sediments located far from the coast and along arid areas with no or small river discharge (Heusser and 
Morley 1985; Hooghiemstra et al. 1986), whereas fluvial transport is especially dominant in humid areas and at sites close to river mouths (Hooghiemstra et al. 1992).

By reviewing a large set of African vegetation reconstructions based on deep-sea pollen records along the African ocean margins both in low- and mid-latitudinal climatic regions of both hemispheres, we intend to: (i) assess the impact, timing and amplitude of climate changes on the regional vegetation, (ii) study the large-scale vegetation changes, (iii) compare the hydrological variability between the northern and southern hemisphere, and (iv) map the tree pollen distribution through geological times. Specifically, this synthesis will allow us to trace past changes in the African vegetation and to investigate the difference between the variability of tropical/equatorial vegetation and subtropical vegetation (north and south of the equator).

\subsection{CLIMATIC AND OCEANOGRAPHIC SETTINGS AND THEIR IMPACTS ON POLLEN TRANSPORT}

The climate of Africa includes a range of several different types that vary more in rainfall amount than in temperatures (Nicholson and Grist 2003). Owing to its position across equatorial and subtropical latitudes in both the northern and southern hemisphere we can distinguish the equatorial climate, the tropical wet and dry climates, the tropical monsoon climate, the semi-desert climate (semi-arid), the desert climate (hyper-arid and arid), the subtropical climate and highland climate.

Most of the continent lies within the intertropical zone between the Tropic of Cancer and the Tropic of Capricorn. The climate of Africa depends on the seasonal migration of the tropical rainbelt associated to the Intertropical Convergence Zone (ITCZ). The ITCZ is a seasonally migrating low-pressure belt that forms where the Northeast (NE) Trade Winds converge with the Southeast (SE) Trade Winds (Nicholson and Grist 2003). During boreal summer, between July and September, the ITCZ reaches its northernmost position bringing moist air upward. This causes water vapour to condense resulting in a band of heavy precipitation over the northern tropicalsubtropical areas as a humid monsoon flow bringing most of the annual rainfall (Nicholson and Grist 2003). A contrasting dry season develops during the boreal winter, from December to February, when the ITCZ reaches its southernmost position causing dry conditions in the northern subtropics associated with strong NE Trade Winds and humid conditions in the southern subtropical regions.

The northernmost and the southernmost edges of the continent have a Mediterranean climate controlled respectively by variations in the North Atlantic Oscillation (NAO) (Le Houérou et al. 1986) and by the position and strength of the South Atlantic anticyclone and the Indian Ocean anticyclone (Shannon 1985; Shannon and Nelson 1996). The climate of Africa is predominantly tropical due to its latitudinal position in relation to the equator and the tropics (Nicholson 2000). Temperate climates are rare across the continent except at high elevations and along the edges.

African deserts are the sunniest and the driest parts of the continent, owing to the prevailing presence of the subtropical ridge with subsiding, hot, dry air masses such as the Saharan Air Layer (SAL), a mid-tropospheric zonal wind system occurring at higher altitudes $(1500-5500$ $\mathrm{m}$ ), incorporating the African Easterly Jet (AEJ). SAL is responsible for transporting dust and terrestrial remains such as pollen grains from the Sahara and Sahel belt to the Atlantic Ocean (Colarco et al. 2003; Hooghiemstra et al. 1986; Prospero and Nees 1986; Prospero et al. 2002; Stuut et al. 2005).

The coast of the Gulf of Guinea, in tropical and equatorial Africa, is characterized by high rainfall and consequently several river systems that complement the aeolian transport of pollen grains. Therefore, fluvial-transported pollen is expected to dominate the pollen assemblages found in marine sediments offshore tropical rivers such as Senegal, Niger, Congo and Cunene Rivers. Further south, the climate system of southern Africa is controlled by the position and 


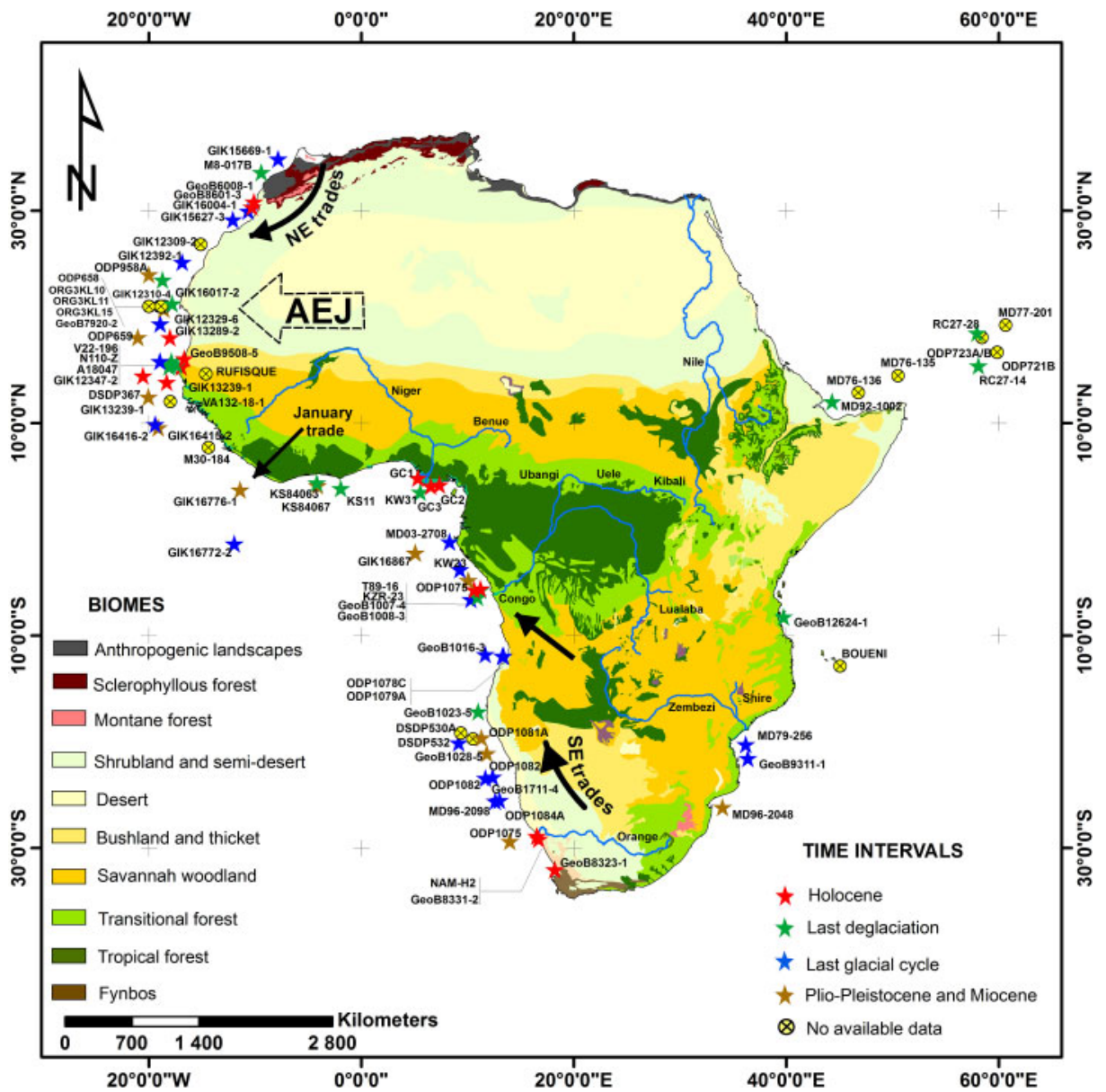

Figure 1. Map of the modern vegetation simplified after White (1983) with the locations of all African marine sites.

strength of the South Atlantic anticyclone and the Indian Ocean anticyclone (Shannon 1985; Shannon and Nelson 1996). The pressure difference between the South Atlantic anticyclone and the continental pressure field causes alongshore SE trade winds (Figure 1). SE trade winds are the main transport agent of pollen from Namibia and western South Africa. Orange River has shown little to no contribution to the pollen content of the adjacent marine sites (Meadows et al. 2002). Along the SE African coast, conditions are dominantly warm and moist, due to the influence of the warm Indian Ocean and Agulhas Western Boundary Current. Moisture is advected from the tropical Indian Ocean mainly during summer months when precipitation often exceeds 100 mm per month (Nash and Meadows 2012) in north-eastern South Africa (Tyson 1986; Tyson and Preston-Whyte 2000). Fluvial transport of pollen grains by Limpopo and Zambezi Rivers is also considerable in this area. Regarding the Gulf of Aden site, the area is dominated by the Indian monsoon (Almogi-Labin et al. 2000).

The wind systems influence the most important large-scale oceanographic features along the African continent. The Canary Current, a wind-driven surface current that is part of the North Atlantic Gyre, dominates the ocean circulation in northwest Africa. This eastern boundary current branches south from the North Atlantic Current due to intensified NE trade winds and flows 
southwest about as far as Senegal where it turns west and later joins the Atlantic North Equatorial Current. Further south, the west coast of southern Africa is dominated by the northward flowing Benguela Coastal Current (BCC) stretching from $34^{\circ} \mathrm{S}$ to $15^{\circ} \mathrm{S}$. The SE African continental shelf is dominated by the Agulhas Current. Hooghiemstra et al. (2006) suggests that the distribution of pollen over the ocean surface is reflected in the marine sediments without substantial displacement by marine currents. This might not be fully true (Fischer et al. 2009), but isopollen maps show that on continental scales the displacement by ocean currents is not large enough to bias the trends seen in the pollen distribution (Dupont and Agwu 1991; Hooghiemstra et al. 1986). We therefore assume that no large-scale transport has displaced the palynomorphs and other terrigenous material while sinking through the water column.

Modern vegetation distribution in Africa reflects the north-south precipitation gradient (Figure 1). The present-day African vegetation around the equator consists of tropical forests including evergreen rainforest in the Congo basin and in the moist part of West Africa and semievergreen and deciduous forest in northern Cameroon and southern Congo. North and south of the forest fringes there is a narrow belt of natural grass savannah. North of the xerophytic shrubland of the Sahel zone and along the coast of Namibia and southwest Angola, desert vegetation occurs (White 1983). Mediterranean vegetation containing trees and shrubs dominate the northern and the southernmost regions of Africa. Coastal vegetation is represented by mangrove, occurring in tropical/subtropical estuaries and near the river mouths (White 1983). The distribution of mangrove depends on water salinity, river runoff, and humidity (Blasco 1984).

\subsection{COMPILATION OF THE RECORDS}

In this study, we use all the available marine pollen records from Africa with an appropriate age model stored in the African Pollen Database (APD) and Pangaea as well as those delivered by authors upon request. Out of 95 marine sites illustrated in Figure 1, only 60 pollen records have the potential to document the vegetation response to climate variability and, therefore, have been used in this paper (Supporting Online Material [SOM] Appendix Table 1).

All of the radiocarbon-dated records considered here have age models in calendar years (cal kyr BP) after conversion of ${ }^{14} \mathrm{C}$ dates to calendar age according to Stuiver et al. (2020). The age models were directly retrieved from the published articles or from the APD (i.e. based on linear interpolation between the dated samples) taking into account the marine reservoir age of 400 years, which reflects the present-day global average (Hughen et al. 2004). Age models beyond the limit of radiocarbon dating were based on the marine oxygen isotope stratigraphy. Selected sites with sufficient temporal resolution were used to illustrate the different patterns of the vegetation response to major climatic events in a centennial-, millennial- and orbital-time scale (Figures 2, 3 and 4). The whole dataset was then used to map tree pollen distribution in marine sediments off African shores at a continental scale throughout different climate cycles (Figure 5). Tree pollen types include trees, shrubs, palms and lianas. Percentages are calculated against a sum of total pollen excluding those of aquatics (including Cyperaceae) and Pinus (SOM Appendix Table 2).

\subsection{PATTERN OF VEGETATION CHANGES IN AFRICA}

Here, we focus on changes in pollen records during four main time intervals; the last deglaciation, the last glacial cycle, the mid-Pleistocene and the Plio-Miocene. To be selected for further analysis, the sites had to cover at least parts of these intervals, with a sufficient temporal resolution for a substantial part of the record, and sufficient age control to pinpoint centennial- or millennialscale changes. Only eight records of the last deglaciation, eight records of the last glacial cycle, 


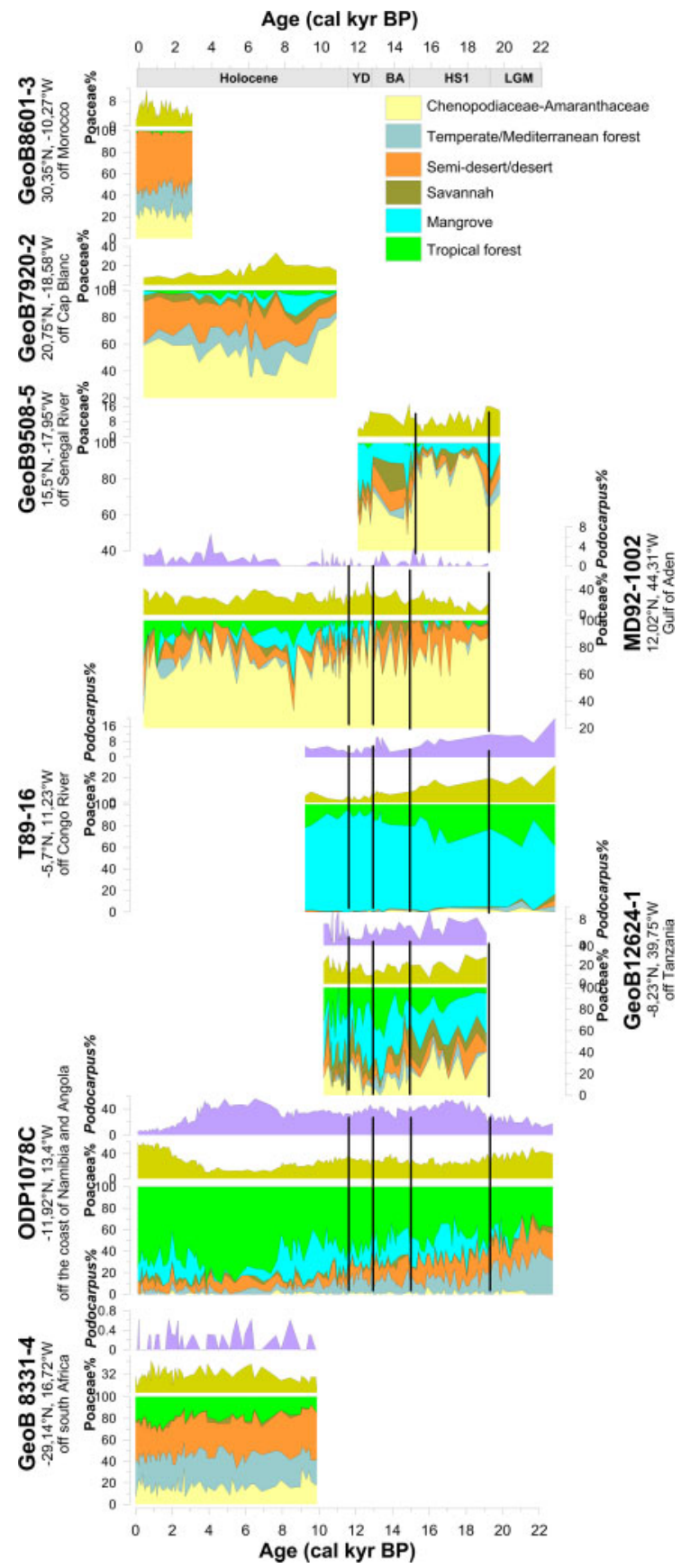

Figure 2. Summary diagrams showing a south-north transect of vegetation changes during the last deglaciation, using the groups given in Table 1, for African marine sites (right hand axes: eastern African margin, left hand axes: western African margin). Additional indicators such as Poaceae (corn yellow) and Podocarpus pollen (lila) are shown for each site in percentages of total pollen (Y-axes). Note the absence of Podocarpus pollen in the northern records. YD: Younger Dryas, BA: Bølling-Allerød warm event, HS1: Heinrich Stadial 1, LGM: Last Glacial Maximum. Black vertical lines are denoting the LGM, HS1, BA, YD and the Holocene for each record. 


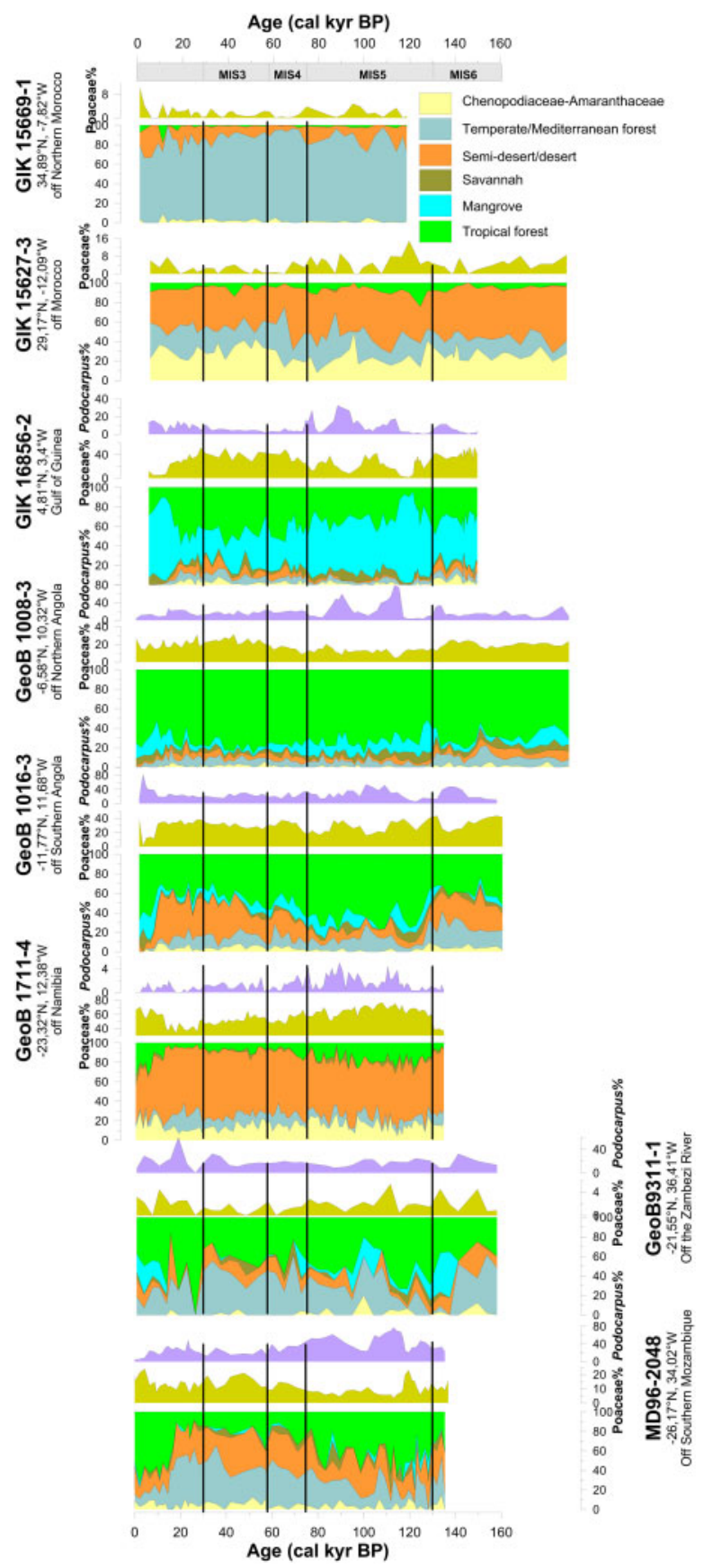

Figure 3. Summary diagrams showing a south-north transect of vegetation changes during the last glacial cycle, using the groups given in Table 1, for African marine sites (right hand axes: eastern African margin, left hand axes: western African margin). Additional indicators such as Poaceae (corn yellow) and Podocarpus pollen (lila) are shown for each site in percentages (Y-axes). Note the absence of Podocarpus pollen in the northern records. MIS: Marine isotope stage. Black vertical lines are delimiting MIS5, MIS4 and MIS3 for each record. 

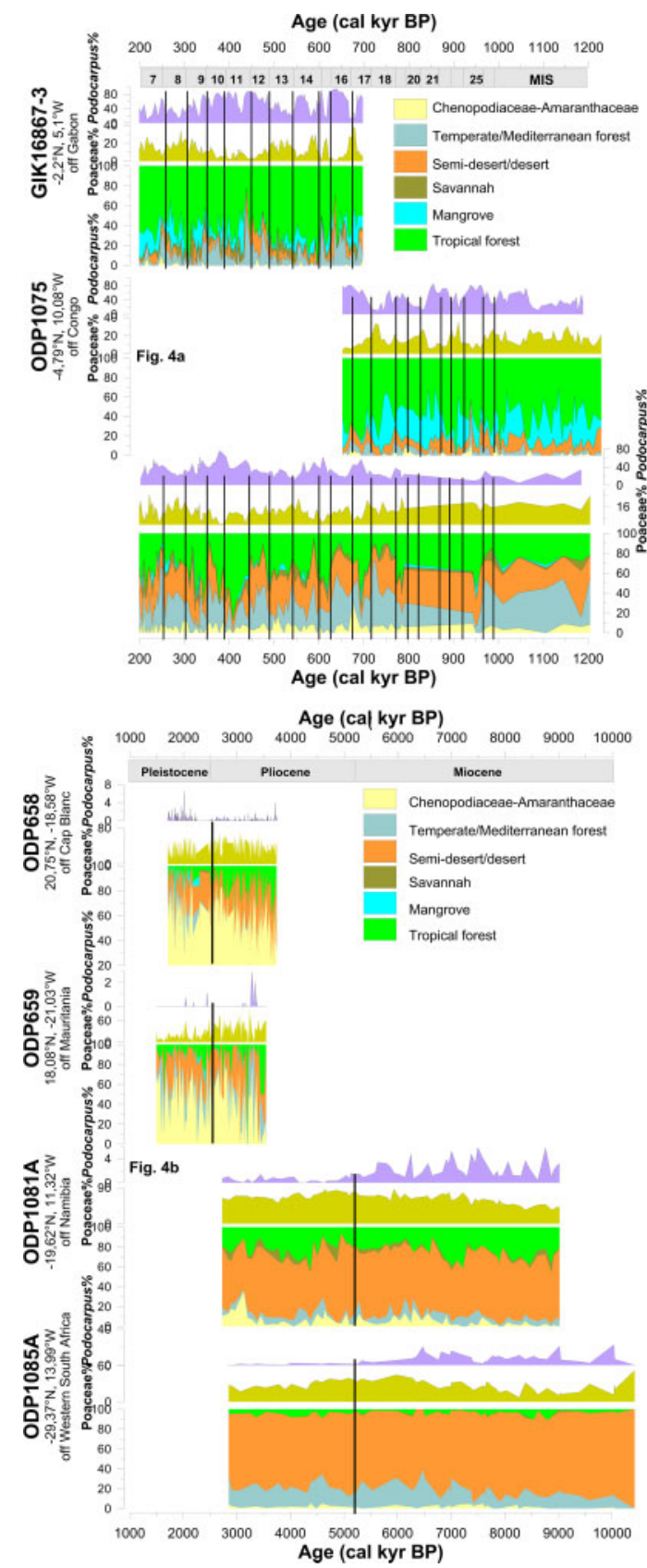

Figure 4. Summary diagrams showing a south-north transect of vegetation changes during (A) the Mid-Pleistocene, and (B) the Plio-Miocene using the groups given in Table 1, for African marine sites (right hand axes: eastern African margin, left hand axis: western African margin. Additional indicators such as Poaceae (corn yellow) and Podocarpus pollen (lila) are shown for each site in percentages (Y-axes). MIS: Marine isotope stage. Black vertical lines are delimiting the different MISs in Figure 4A and are separating the Miocene, the Pliocene and the early Pleistocene in Figure 4B. 
three mid-Pleistocene and four Plio-Miocene records met these criteria (Figure 2, 3 and 4). Differences in regional floras make it difficult to compare pollen records from different regions directly. To facilitate comparisons between sites, the vegetation records are summarized in terms of major vegetation types (biomes) (Table 1). This naturally involves a certain loss of information, but allows us to describe the main vegetation changes for each record (Figure 2, 3 and 4) in a consistent way. It also should be kept in mind that the selection of pollen types reduces the sums on which percentage calculation is based.
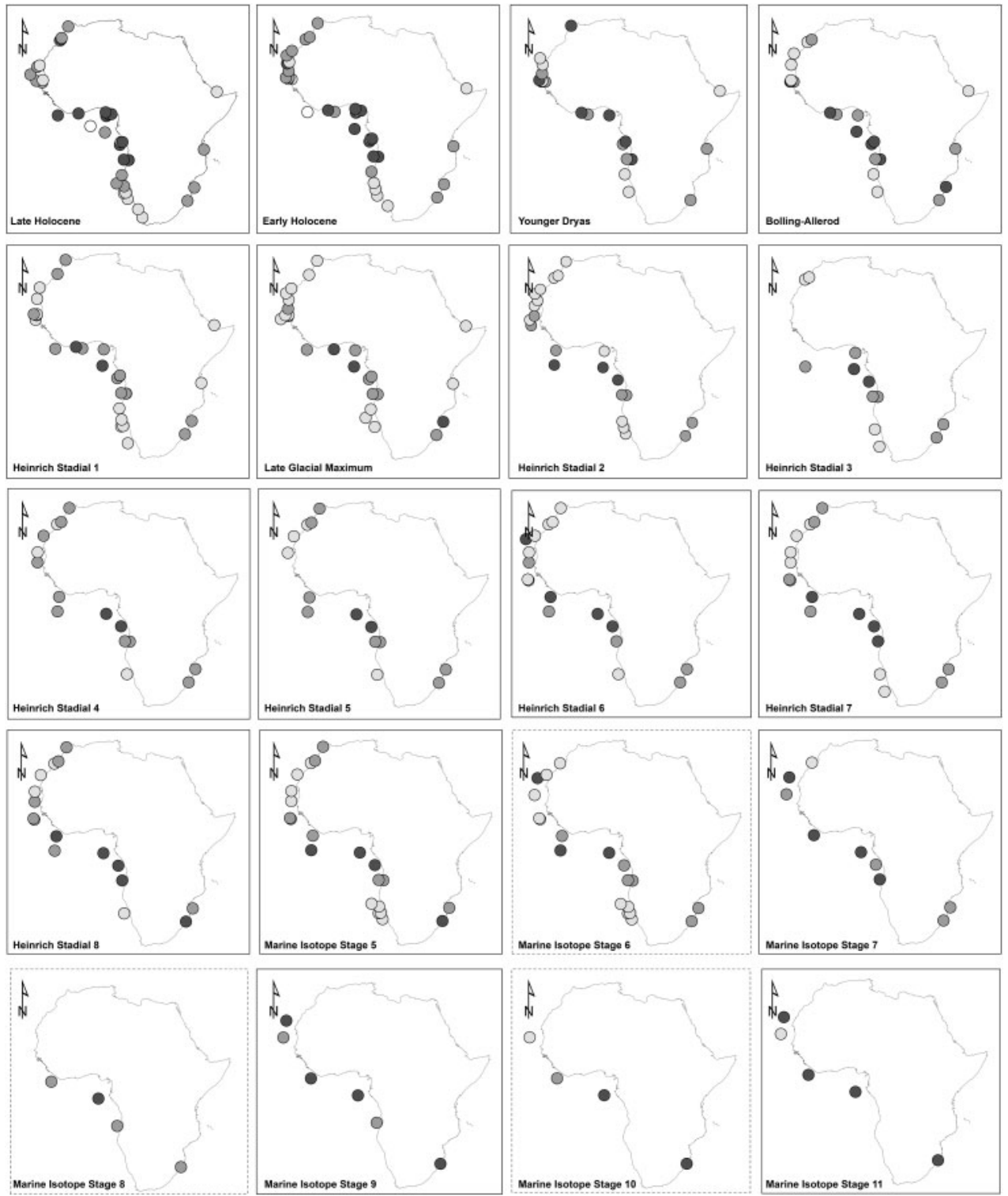

(Continued) 

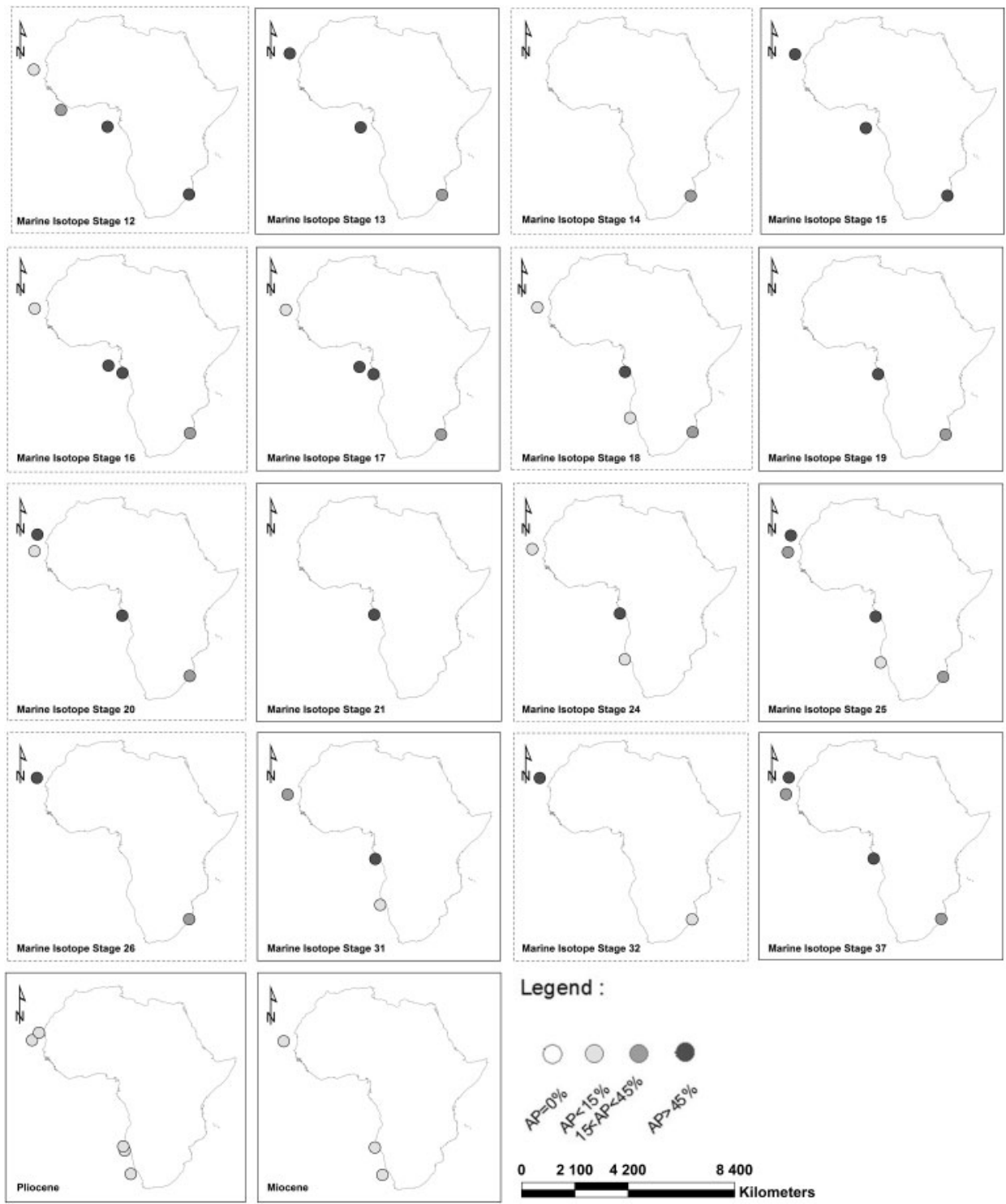

Legend :

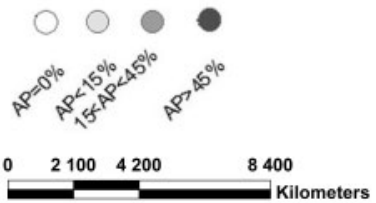

Figure 5. Spatial distribution of tree pollen percentages in African marine sediments. Four categories are considered. Black dot: AP $>45 \%$ showing high percentages of arboreal taxa, grey dot: $15<\mathrm{AP}<45 \%$ intermediate percentages of arboreal taxa, light grey dot: $\mathrm{AP}<15 \%$ weak percentages of arboreal taxa and white dot: $\mathrm{AP}=0 \%$ absence of arboreal taxa. Dashed boxes, indicate cold stages and solid boxes denote warm stages.

\subsubsection{Last deglaciation and Holocene}

The ODP1078C from southwestern (SW) Africa (Dupont et al. 2008) and MD92-1002 from eastern Africa in the Gulf of Aden (Fersi et al. 2016) provide continuous pollen records of the last 20,000 years with high temporal resolution (SOM Appendix Table 1, Figure 2). The other pollen records cover either the early part of the last deglaciation or the Holocene (Figure 2). 
Table 1. List of the African biomes and characteristic pollen taxa grouped in major vegetation types according to the phytogeographical assignment.

\begin{tabular}{|c|c|c|}
\hline Mega-Biome & $\begin{array}{l}\text { Equivalent local } \\
\text { vegetation names }\end{array}$ & $\begin{array}{l}\text { Characteristic } \\
\text { pollen taxa }\end{array}$ \\
\hline Temperate/ & $\begin{array}{l}\text { Cool temperate rain } \\
\text { forest }\end{array}$ & $\begin{array}{l}\text { Azioaceae, Cedrus, Ericaceae, } \\
\text { Juniperus, Olea, Pinus, } \\
\text { Pistacia, Quercus, } \\
\text { Restionaceae }\end{array}$ \\
\hline Mediterranean forest & $\begin{array}{l}\text { Warm-temperate forest } \\
\text { Fynbos }\end{array}$ & \\
\hline \multirow[t]{3}{*}{ Semi-desert/Desert } & Desert shrubs & $\begin{array}{l}\text { Artemisia, Asteroideae, } \\
\text { Cichoroideae, Ephedra, } \\
\text { Plantago, Ziziphus, } \\
\text { Zygophyllum }\end{array}$ \\
\hline & Grass & \\
\hline & Herbs & \\
\hline CCA & $\begin{array}{l}\text { Desert and halophytic } \\
\text { vegetation }\end{array}$ & $\begin{array}{l}\text { Amaranthaceae, } \\
\text { Caryophyllaceae }\end{array}$ \\
\hline \multirow[t]{3}{*}{ Savannah } & Dry forest & $\begin{array}{l}\text { Acacia, Spermacoce, Boscia, } \\
\text { Celtis, Cleome, Mimosaceae, } \\
\text { Mitracarpus }\end{array}$ \\
\hline & Steppe & \\
\hline & $\begin{array}{l}\text { Savannah } \\
\text { grassland }\end{array}$ & \\
\hline Mangrove & Mangrove & Avicennia, Rhizophora \\
\hline \multirow[t]{3}{*}{ Tropical forest } & Tropical lowland forest & $\begin{array}{l}\text { Alchornea, Allophylus, } \\
\text { Arecaceae, }\end{array}$ \\
\hline & Tropical evergreen forest & $\begin{array}{l}\text { Berlina/Isoberlina, } \\
\text { Bignoniaceae, Blighia, } \\
\text { Bombacaceae, Borassus, } \\
\text { Brachystegia, Butyrospermum, } \\
\text { Canthium, Capparis, Cassia, } \\
\text { Combretaceae, Croton, } \\
\text { Cuviera, Daniellia, Diospyros, }\end{array}$ \\
\hline & $\begin{array}{l}\text { Tropical semi-deciduous } \\
\text { forest }\end{array}$ & $\begin{array}{l}\text { Dodonaea, Elaeis, Ficus, } \\
\text { Gaertnera, Hippocrateaceae, } \\
\text { Hygrophila, Hymenocardia, } \\
\text { Ilex, Indigofera, Ixora, } \\
\text { Lannea, Leea, Mallotus, } \\
\text { Manilkara, Melochia, } \\
\text { Ochna, Parinari, Phoenix, } \\
\text { Phyllanthus, Piliostigma, } \\
\text { Pterocarpus, Rhamnaceae, } \\
\text { Rhus, Schreberea, Sterculia, } \\
\text { Stereospermum, Syzygium, } \\
\text { Tamarindus, Tarenna, } \\
\text { Trichilia, Uapaca, Urticaceae, } \\
\text { Vitaceae, Ximenia, } \\
\text { Zanthoxylum }\end{array}$ \\
\hline
\end{tabular}


In Equatorial Africa, the pollen record of T89-16 (Marret et al. 2001) (Figure 2) provides information into the equatorial vegetation development reflecting environmental changes in the Congo basin prior to the Holocene. We excluded core KW 31, located south of the Niger Delta (Lézine and Cazet 2005), despite a sufficient time resolution due to substantial gaps in the pollen record (SOM Appendix Table 1). The GeoB9508-5 off the Senegal River and GeoB12624-1 off the Rufiji Delta, (Bouimetarhan et al. 2012; 2015) show high-resolution vegetation change during the northern hemisphere cold Heinrich Stadial 1 (HS1; c. 18-15 kyr BP) (McManus et al. 2004) and the Younger Dryas (YD; c. 12.9-11.6 kyr BP) (Rasmussen and Thomsen 2015) (Figure 2). The Holocene records are represented by the high-resolution GeoB8331-4 and GeoB7920-2 pollen records (Dupont and Schefuß 2018; Zhao et al. 2016) covering the last 10,000 years and the GeoB8601-3 pollen record covering the last 3000 years (Zhao et al. 2019) (Figure 2).

In southern Africa, the ODP1078C pollen record off the coast of Namibia and Angola shows a clear dominance of semi-desert vegetation and Poaceae during the Last Glacial Maximum (LGM), which decreases slightly during the Heinrich Stadial (HS) 1 while tropical forest and mangrove as well as Podocarpus increased, indicating wetter and cooler climate conditions. This trend is almost stable until the Holocene. However, from 10 to $8 \mathrm{kyr}$ BP, a slight increase in mangrove is observed reflecting a continuous input freshwater supply, which decreases in favour of the tropical forest and Podocarpus (reaching up to 54\%) from 8 until $3 \mathrm{kyr}$ BP. After $3 \mathrm{kyr}$ BP Poaceae increase rapidly up to $40 \%$ possibly reflecting a shift towards drier conditions, although human impact cannot be excluded.

In eastern Africa, the MD92-1002 pollen record from the Gulf of Aden shows rather a contrasting trend. The last deglacial vegetation is dominated mainly by CCA (Caryophyllaceae and Amaranthaceae including Chenopodiaceae) and Poaceae. CCA reach up to $\sim 58 \%$ and $45 \%$ during HS1 and YD respectively along with semi-desert/desert vegetation indicating the extremely dry climatic conditions during the North Atlantic cold stadials. A slight increase in the savannah is observed during the time period equivalent to the northern hemisphere warm event known as the Bølling-Allerød (BA; c. 14.7 to $12.8 \mathrm{kyr}$ BP) (Rasmussen et al. 2006). The onset of the Holocene (c. 11.7 kyr BP) exhibits a substantial decrease in CCA and semi-desert representation along with an increase in savannah elements as well as the tropical forest and mangrove indicating a shift towards relatively wetter climatic conditions until $5 \mathrm{kyr}$ BP. Podocarpus pollen is present in very low relative abundances during the $\mathrm{BA}$ and late Holocene testifying rather the long-distance wind transport.

In equatorial Africa, the pollen record off the Congo River T89-16 shows a constant dominance of the mangrove forest throughout the whole sequence reaching up to $78 \%$ during the YD. High abundances of mangrove pollen have been associated with transgressive phases and large flood of the Congo River (Scourse et al. 2005). Poaceae and Podocarpus exhibit simultaneously higher percentages during the LGM indicating cooler climate and decrease dramatically during the YD.

In western and eastern Africa, pollen records off Senegal (GeoB9508-5) and off Tanzania (GeoB12624-1) cover partly the period between $c .19$ and $12 \mathrm{kyr}$ BP, at centennial- to subcentennial-resolution, and provide new information on the deglacial vegetation of these regions, which shows contrasting vegetation changes. Using last deglaciation pollen records from the continental slope off Senegal, the data show that the Sahel drought remained severe during HS1 with maximum CCA representation along with elements from the savannah and semidesert/desert vegetation, while Poaceae are represented before and after HS1. The marine pollen record off the Rufiji River shows low percentages of CCA during HS1 along with high percentages of tropical forest, savannah elements and mangrove as well as Podocarpus indicating less severe HS1 droughts in contrast to West Africa.

The Holocene records off northwest (NW) Africa (GeoB7920-2) and South Africa (GeoB8331-4) show similar trends with a clear dominance of three biomes, the semi-desert/desert vegetation and CCA, the Mediterranean forest, and fynbos. While the latter is rather constant 
throughout the Holocene, the former shows a clear decrease in CCA and semi-desert/desert vegetation during the early Holocene followed by a remarkable increase after $c$. $5 \mathrm{kyr}$ BP. Poaceae reach their maximum values between $c .10$ and $6 \mathrm{kyr}$ BP. The short record of GeoB8601-3 offshore Morocco shows a constant dominance of semi-desert/desert vegetation with a clear increase in Poaceae pollen during the last 1000 years.

\subsubsection{Last glacial cycle}

Eight sites, of which two sites from the eastern African margin have been selected for this time interval (Figure 3). In northern Africa, a record of maximum extension of the Mediterranean forest is found at the northernmost site off northern Morocco, GIK15669-1 at $34^{\circ} \mathrm{N}$ (Hooghiemstra et al. 1992) during the last glacial cycle, which is coincident with a similar forest expansion in Europe (e.g. Sánchez Goñi et al. 1999). The GIK15627-3 pollen record off southern Morocco at $29^{\circ} \mathrm{N}$ (Hooghiemstra et al. 1992) depicts a different pattern with a clear dominance of CCA and semi-desert/desert vegetation. Although lower than the previous record, a slight extent of the Mediterranean forest is observed for Marine Isotope Stage (MIS) 5 that continues until the present along with Poaceae that decrease however, rapidly after MIS5.

In equatorial Africa, the GIK16856-2 pollen record offshore Guinea at $5^{\circ} \mathrm{N}$ (Dupont and Weinelt 1996) shows an extension of mangrove forest during MIS5 and the last 20,000 years along with a minimum representation of Poaceae pollen reflecting moist continental conditions that coincide with interglacial and last deglacial conditions, respectively. Podocarpus percentages show maxima during the latter part of MIS5 indicating a well-developed Afromontane forest as a response to a cooler climate during the stadials MIS5b and MIS5d.

Further south, maximum expansion of the tropical forest is observed at the complete equatorial site GeoB1008-3 at $6^{\circ} \mathrm{S}$ offshore northern Angola (Jahns 1996). MIS 5 exhibit low Poaceae percentages while Podocarpus reach their highest values indicating a cooler climate during the stadials of MIS5. In contrast to the previous record, mangrove forest is less represented along with other biomes. The pollen record GeoB1016-3 off Southern Angola at $11^{\circ} \mathrm{S}$ (Shi and Dupont 1997) shows a contrasting pattern compared to the previous records. Here, we see a clear dominance of the semi-desert/desert vegetation along with Poaceae pollen except for MIS5 where tropical forest and to a lesser extent mangrove are well developed. Podocarpus is well developed during MIS5c-d and the last 10,000 years of the record. The record of GeoB1711-4 (Shi et al. 2001) from the Namib Desert shows a constant dominance of semi-desert/desert vegetation and Poaceae with the presence of CCA. However, a small but significant increase in tropical forest and Podocarpus pollen is observed during the stadials of MIS5 reflecting slightly cooler conditions.

In eastern Africa, the MD96-2048 pollen record from southern Mozambique at $26^{\circ} \mathrm{S}$ shows a clear shift from tropical forest dominance during MIS5 to semi-desert/desert vegetation and Mediterranean forest dominance afterwards (Dupont et al. 2011). In contrast, the GeoB9311-1 pollen record off the Zambezi catchment at $21^{\circ} \mathrm{S}$ (Dupont and Kuhlmann 2017) shows a codominance of tropical and temperate forests for the entire record. On the other hand, Podocarpus pollen is very well represented during MIS5 in the southern record while they do not exceed $20 \%$ in the northern record. This suggest that on a regional scale climatic perturbations of the vegetation cover in the Zambezi catchment are less severe than in southern Mozambique.

\subsubsection{Mid-Pleistocene}

Three pollen records were selected to assess glacial-interglacial fluctuations in the vegetation records around Africa during the Mid-Pleistocene (between c. 1.2 and 0.4 Million years (Myr) BP; Berger and Jansen 1994) (Figure 4A). In eastern Africa, the recently published pollen record off southern Mozambique MD96-2048 at 26ㅇ (Dupont et al. 2019) represents a unique and continuous high-resolution African record from the Indian Ocean, to study the long-term 
evolution of orbital-scale vegetation changes. The terrestrial pollen assemblages indicate that during glacials, specifically during MIS 7, 9, 11, and 17, the vegetation of eastern South Africa and southern Mozambique largely consisted of tropical forest vegetation indicating relatively wet conditions. During glacials, Mediterranean elements (here represented by the ericaceous vegetation in the mountains) along with semi-desert/desert elements dominated the pollen assemblage. Podocarpus pollen does not display variability related to glacials or interglacials.

In equatorial Africa, represented by the ODP1075 pollen record off Congo at $4{ }^{\circ} \mathrm{S}$ (Dupont et al. 2001) and GIK16867-3 record off Gabon at $2^{\circ} \mathrm{S}$ (Dupont et al. 1998), vegetation is mainly dominated by tropical forest and mangrove. The tropical forest expands widely during interglacials (MIS 7, 9, 11, 13, 15, and 17) along with mangrove in sites offshore Gabon, while the semi-desert/desert vegetation slightly increases during the glacials. Podocarpus shows higher percentages during glacials indicating the expansion of mountainous forest during cold periods. The ODP 1075 pollen record shows a much higher representation of mangrove forest along with tropical forest increasing strongly during periods of sea-level rise (Scourse et al. 2005). Poaceae show rather lower values during interglacials MIS17, 19, 21, and 25 while Podocarpus does not show a clear trend.

\subsubsection{Plio-Miocene}

Four records are presented here to reconstruct Miocene (c. 23 to $5.3 \mathrm{Myr}$ BP) to Pliocene (c. 5.3 to $2.5 \mathrm{Myr} \mathrm{BP}$ ) changes of African vegetation and rainfall regime (Figure 4B). In SW Africa, the South Atlantic ODP1085A pollen record at $29^{\circ} \mathrm{S}$ (Dupont et al. 2019) consists mainly of a strong representation of desert and semi-desert vegetation and Poaceae pollen implying that conditions were already arid $10 \mathrm{Myr}$ ago. Podocarpus exhibit elevated relative abundances during the Miocene while it disappears quasi-completely during the Pliocene. Authors have inferred changes in the relative amount of precipitation and indicated a shift of the main moisture source from the Atlantic to the Indian Ocean during the onset of a major aridification $8 \mathrm{Myr}$ ago (Dupont et al. 2013). The ODP1081A pollen record (Hötzel et al. 2015) offshore Namibia covering the time interval between 9 and 2.7 Myr BP consists mainly of pollen from semi-desert/desert vegetation. While, Podocarpus occurred during the Miocene, grasses expanded during the Pliocene.

In NW Africa, the Plio-Pleistocene pollen record ODP659A at $18^{\circ} \mathrm{N}$ (Vallé et al. 2017) shows more variability in the pollen content. After 3.5 Myr BP, the abrupt increase of CCA and Poaceae suggests larger climate variability during that interval implying continent-wide aridity during eccentricity maxima between 3.2 and 2.5 Myr BP. From 2.5 Myr BP on, the trend in ODP Site 659 is characterized by a slight increase of Mediterranean forest and semi-desert/desert vegetation and a clear decrease in Poaceae pollen. Podocarpus pollen are present during the Pliocene with very low relative abundances but quasi-absent during the early Pleistocene. The ODP658 pollen record off Cap Blanc at $20^{\circ} \mathrm{N}$ (Leroy and Dupont 1994) shows a similar trend as ODP659 during the late Pliocene. However, Poaceae pollen that reach up to 59\% during the Late Pliocene continue to be well represented through the early Pleistocene. Podocarpus, similarly to the ODP site 659, is present with very low percentages during the late Pliocene and between 1.7 and 2 Myr BP.

\subsection{POLLEN-CLIMATE RELATIONSHIP IN AFRICA}

Today, Africa is mainly dominated by open landscapes between $30^{\circ} \mathrm{S}$ and $30^{\circ} \mathrm{N}$ with the exception of the Mediterranean, equatorial and mangrove forests and the afromontane forests. These open landscapes range from desert, dry forests, to woodlands, wooded grasslands, grasslands, and fynbos (White 1983). Transitions between forest, savannah and desert vegetation types as well as Mediterranean forest in African fossil pollen records are often poorly understood due 
to the scarcity of modern pollen-vegetation studies (Julier et al. 2018; Lézine and Hooghiemtra, 1990; Vincens et al. 2000) and the over-representation/under-representation of certain taxa. Shifts in biome distributions imply significant changes in climate, especially the precipitation gradient throughout several time scales, reflecting a change in monsoon extent combined with a southward expansion of the ITCZ (Shanahan et al. 2015). Outside the influence of the monsoon, westerly storm tracks bring rainfall to the northernmost and southernmost parts of Africa (Jolly et al. 1998). Additionally, biomes are differently represented, because the biome characteristic taxa have very different pollen production rates with different pollination strategies (entomophily (insects); lepidopterophily (butterflies); anemophily (wind); chiropterophily (bats); and ornithophily (birds)), and different dispersal mechanisms. Forest taxa which are frequently entomophilous are under-represented (Vincens et al. 2000), while anemophilous taxa such as Poaceae are generally over-represented relative to their abundance in the vegetation (Bush and Rivera 1998). Pollen of Combretaceae and Alchornea are better represented in the marine sediments than other trees due to the better pollen dispersal compared to many other tropical forest trees (Dupont 2011; Watrin et al. 2007). Although, the relative abundances of pollen grains cannot be simply translated into vegetation composition, it could be interpreted as relative changes of biomes through time. In marine sediments, this issue becomes even more serious as fossil pollen records effectively show only a part of the vegetation on the adjacent continent. The reduced representation of the assemblage is less in pollen data from terrestrial deposits, which give more local information. However, due to the relatively good preservation of pollen grains in certain marine records, good age control and coverage of long periods, marine archives allow us to study vegetation changes over several continuous climate cycles. Here, we present distribution maps of arboreal pollen percentages (AP\%) from available marine pollen records off African shores for different time-slices (Figure 5) in order to discuss changes in regional vegetation and environmental conditions over orbital and glacial-interglacial timescales and to assess the lowto mid-latitude interhemispheric climatic implications and mechanisms.

\subsection{PATTERN OF LANDSCAPE CHANGES}

We show four arboreal taxa categories (AP\%), as also used by Lézine et al. (this issue), to characterize the African landscapes through several climate cycles (Figure 5): (i) AP higher than $45 \%$ corresponding to more or less closed canopy, (ii) $15<\mathrm{AP}<45 \%$ intermediate between closed canopy and open landscapes, (iii) AP lower than $15 \%$ indicating grass-dominated landscapes, and (iv) $\mathrm{AP} \%=0$.

During the early Holocene, marine pollen records show high percentages (AP $>45 \%$ ) of arboreal taxa in most of Africa. Exceptions are found offshore of SW Africa (South Africa and Namibia), Gulf of Aden and Mauritania. This indicates the prevalence of forested vegetation types over tropical and Mediterranean Africa linked to humid conditions. Late Holocene records show a more open landscape as many sites contain lower relative abundances of arboreal taxa $(\mathrm{AP}<15 \%)$ reflecting grass dominated landscape, thus drier conditions than in the early Holocene.

Between 21 and $11.8 \mathrm{kyr}$ BP, last deglaciation marine pollen records show a more open vegetation with widespread grassland, as well as savannah and xerophytic scrubland vegetation (Figure 2) indicating dry climate especially during the last glacial maximum (LGM). AP\% are higher $(>45 \%)$ in Equatorial Africa and in NW and SE Africa even during HS1 and LGM whereas the rest of the marine African pollen records are characterized by a strong representation of grasses.

Between 50 and $21 \mathrm{kyr}$ BP, open grasslands and savannahs dominate NW and SW Africa, the tropical regions and SE Africa show a mixture between closed canopy and open landscapes, while equatorial Africa is characterized by a more or less dense vegetation during HS2 and HS3. In general, HS4 and HS5 display intermediate $\mathrm{AP} \%(15<\mathrm{AP}<45 \%)$ indicating relatively wetter conditions. 
Between 80 and $50 \mathrm{kyr}$ BP, pollen records show that HS6 is characterized by a return to a more open vegetation and thus, drier conditions in NW Africa and Gulf of Guinea compared to the previous HS. HS7 and HS8 exhibit similar trends as HS4 and HS5 with particularly higher $\mathrm{AP} \%(>45 \%)$ during HS8 in SE Africa. Taken together the AP\% distributions over the last 80,000 years show, to a certain extent, a north-south rainfall gradient consisting of lower $\mathrm{AP} \%(<15 \%)$ in NW and SW Africa, intermediate AP\% in tropical Africa and SE Africa and higher AP\% in equatorial Africa. Although marine pollen records from eastern Africa are extremely understudied compared to western Africa, we could observe a contrast between the relatively denser SE and the open SW African landscape; forests only occurred in western equatorial Africa between $2^{\circ} \mathrm{N}$ and $12^{\circ} \mathrm{S}$. The AP\% distribution maps show that the intervals spanning the LGM, HS1 HS2 and HS6 are marked by an increase in open vegetation, mainly savannah and xerophytic vegetation as shown in Figure 5. These changes occur mainly in NW and SW Africa indicating that major changes in biome distributions occurred north of $10^{\circ} \mathrm{N}$ and to a certain extent south of $20^{\circ} \mathrm{S}$.

\subsubsection{Interglacials vs. glacials}

For MIS5, one of the best studied warm stages in Africa represented by 21 records, open landscapes dominate the Sahel/Sahara region from $20^{\circ}$ to $30^{\circ} \mathrm{N}$ and SW Africa and decline in 12 sites located in western equatorial Africa, north and SE Africa where intermediate and higher $\mathrm{AP} \%$ are more prominent. This indicates a relatively wetter climate during MIS5 compared to the previous period. During MIS6 (represented by 19 records), open landscapes dominate the coast between $30^{\circ} \mathrm{N}$ and $9^{\circ} \mathrm{N}$ indicating a southward shift of the savannah biome during this glacial period. MIS7 (represented by nine records) shows a clear dominance of arboreal taxa except one site offshore Morocco indicating a return to wetter conditions. The next time slices, which are represented with only few sites each (average of 3 to 5 records) seem to follow the pattern of odd- and even-numbered MIS and show an alternation between dense arboreal dominance during MIS9, 11, 13, 15, 17, 19, 21, 25, 31, and 37 and more open vegetation during MIS 10, 12, 14, $16,18,20,24$, and 32, especially in NW and SW Africa.

MIS20 and MIS26 form an exception showing higher arboreal pollen percentages offshore of the Sahara. Moreover, the eastern African site that exhibited intermediate to higher arboreal taxa values throughout all timescales indicated an open-dominated landscape during MIS32 reflecting dry conditions in this area compared to previous climate cycles. The only few available records representing the Pliocene and the Miocene show mostly grass-dominated landscapes and dry forests.

Taken together, the $\mathrm{AP} \%$ distribution maps show that dense forests and intermediate tree cover were able to persist in equatorial and eastern Africa through all marine isotope stages shown in Figure 5 (except MIS32). The scarcity of eastern African marine sites, however, hampers a reliable comparison in order to understand the response of the eastern African biomes to climate variability in this climatically highly complex region.

\subsubsection{Low vs. mid-latitudinal variability}

The influence of obliquity, the tilt of the Earth's rotational axis, on incoming solar radiation at low latitudes is small, yet many tropical and subtropical palaeoclimate records reveal a clear obliquity signal (Dupont 2011; Dupont et al. 1989). This is particularly important since in terms of mean energy balance the integrated summer insolation is more important than maximum insolation, which is influenced by obliquity and not by precession (Huybers 2011). Additionally, the insolation gradient between high and low-latitudes depending on obliquity controls the atmospheric meridional flux of heat, moisture, and latent energy (Raymo and Nisancioglu 2003). Obliquity's control on meridional insolation gradients weaken, or strengthen, the mid-latitude westerlies and the subtropical trade winds (Lee and Poulsen 2005). Yet, model simulations suggest that 
the $c .100 \mathrm{kyr}$ cycle signal was not a robust feature of tropical vegetation, which is subject to stronger direct forcing by the precessional (c. $21 \mathrm{kyr}$ ) orbital cycle (Gosling and Holden 2011). However, Dupont (2011) has shown significant power around $100 \mathrm{kyr}$ at all records she has analysed in her review paper, which is interpreted as an effect of glacial boundary conditions. Thus, the correlation of palaeoenvironmental changes from African pollen records with global temperature change remains ambiguous and must be done with great caution. The AP\% distribution maps (Figure 5) and pollen diagrams (Figure 2) indicate that during the Holocene, YD and HS1, the response of arboreal vegetation reversed at subtropical latitudes between hemispheres, whereby NW African sites exhibit higher AP\% than those of SW Africa. Arboreal taxa values show maxima at equatorial and tropical sites from the northern and southern hemispheres during warm stages (Figure 5) and a clear reduction during cold stages (Figures 3 and 4A) probably driven by summer insolation, which is expected to be the main forcing mechanism of rain forest variability. Summarizing the marine palynological results covering several glacial-interglacial climate cycles, it is suggested that the equatorial rain forest extent in tropical Africa varies with summer insolation; with boreal summer insolation in the northern part and with austral summer insolation in the southern part.

\subsection{PERSPECTIVES}

This paper attempts to review and synthetize all available marine fossil pollen records from offshore marine cores around the African continent to explore the vegetation response to climate changes in millennial- and orbital-timescales. There is a clear need for more and higher resolution records especially from the eastern African shores. There is also a need to improve dating of the key records and create age models. Marine pollen records may be difficult to interpret as they record an integrated mixture of pollen coming from large source areas. Nevertheless, if the dispersal and transport mechanisms as well as the diagenesis and preservation are taken into account, they can be very useful to document latitudinal shifts in biomes and to complement the existing information from terrestrial records. This review was possible thanks to the available data sets of pollen records submitted to different databases and to personal communications with some authors. However, there is still a big amount of missing data that have not been submitted in any database although the corresponding articles have been recently published. Therefore, there is an urgent need to encourage colleagues all over the world to make their data public for the general scientific interest.

\subsection{CONCLUSIONS}

Palynological approaches are moderately useful in distal offshore ocean settings characterized by oligotrophic conditions because of low concentration of palynomorphs, making it difficult to do statistically representative counts. On the other hand, combined with the fundamental problems of tropical palynology (the under-representation of many species in the pollen record), the pollen grains found in marine sediments are typically transported over long distances, through winds and water, making it difficult to identify the precise source area. However, one of the main advantages of pollen records from marine sediment sequences is that they provide access to exceptionally long palaeoecological records that are crucial to understand the vegetation response to climate forcing over time and allow direct correlations of climate change over land and in the ocean, with minimal chronological uncertainty. Marine pollen records offer a unique opportunity to associate continental environmental changes with marine environmental changes inferred from the study of other palynomorphs (dinoflagellate cysts) or other sedimentary, geochemical or micropalaeontological proxies. 
The overview presented here has shown that African vegetation and climate responded to long-term and shorter-term climate changes. There was a dynamic equilibrium between vegetation and climate for short periods of forcing such as the Holocene and HEs. Within the Interglacials (especially MIS5e), the African margin shows a clear dominance of arboreal taxa in most sites (with some exceptions) indicating moist conditions. A different trend has been observed between low- and mid-latitudes. The forest expansion shows maxima during interglacials and a clear reduction during glacials at equatorial and tropical sites from the African northern and southern hemispheres.

This overview has also shown that the western coast of Africa is well documented with continuous pollen records dating back to the Miocene thanks to the commitment of some researchers over the last few decades. The atmospheric circulation conditions that favour pollen transport towards the ocean, the latitudinal distribution of the major biomes as well as the reconstruction of regional vegetation and its response to climate changes are one of the most important outcomes of this research. However, the eastern coast of Africa, a climatically highly complex region, is poorly documented. With the exception of few sites at the mouths of large rivers such as Limpopo, Zambezi and Rufiji, marine pollen records are rare in this part of Africa but extremely important to understand the response of the ecosystems to climate variability. More marine pollen records are therefore, necessary to provide independent evidence into the timing of vegetation changes in a regional context and their connection to global climate. Moreover, they would offer an important complement to previously published palaeorecords from continental archives such as the Great Rift Lakes (Tanganyika, Malawi, Victoria).

\section{ACKNOWLEDGEMENTS}

The authors wish to express their gratitude to all African Pollen Database (APD) contributors and colleagues who made their data available for this study and for the excellent discussions during the APD meeting in Bondy. We thank Henry Hooghiemstra and William D. Gosling for their constructive comments on the manuscript. IB, HR, AB are funded by the German Federal Ministry of Education and Research (BMBF), through the PMARS III grant (PMARS2015-100)". LD by the University of Bremen, and AML by CNRS.

\section{REFERENCES}

Adojoh, O., Marret-Davies, F., Duller, R., Osterloff, P., Oboh-Ikuenobe, F., Hart, M. and Smart, C., 2020, The biostratigraphy of the offshore Niger delta during the Late Quaternary: Complexities and progress of dating techniques. Quaternary Science Advances, 1, pp. 1-7, 10.1016/j.qsa.2020.100003.

Agwu, C.O.C. and Beug, H.-J., 1982, Palynological studies of marine sediments off the West African coast. 'Meteor' Forschungsergebnisse, Deutsche Forschungsgemeinschaft, Geologie und Geophysik, Gebrüder Bornträger, 36, pp. 1-30.

Almogi-Labin, A., Schmiedl, G., Hemleben, C., Siman-Tov, R., Segl, M. and Meischner, D., 2000, The influence of the NE winter monsoon on productivity changes in the Gulf of Aden, NW Indian Ocean during the last $530 \mathrm{kyr}$ as recorded by foraminifera. Marine Micropaleontology, 40, pp. 295-319, 10.1016/S0377-8398(00)00043-8.

Bayon, G., Schefuß, E., Dupont, L., Borges, A. V., Dennielou, B., Lambert, T. and André, L., 2019, The roles of climate and human land-use in the late Holocene rainforest crisis of Central Africa. Earth and Planetary Science Letters, 505, pp. 30-41, 10.1016/j.epsl.2018.10.016. 
Berger, W.H. and Jansen, E., 1994, Mid-Pleistocene Climate Shift, The Nansen Connection. The Polar Oceans and Their Role in Shaping the Global Environment, Geophysical Monograph Series, 85, pp. 295-311.

Blasco, F., 1984, Climatic factors and the biology of mangrove plants. Monographs on Oceanographic Methodology, 8, pp. 18-35.

Bouimetarhan, I., Dupont, L., Kuhlmann, H., Pätzold, J., Prange, M., Schefuß, E. and Zonneveld, K., 2015, Northern Hemisphere control of deglacial vegetation changes in the Rufiji uplands (Tanzania). Climate of the Past, 11, pp. 751-764, 10.5194/cp-11-751-2015.

Bouimetarhan, I., Dupont, L., Schefuß, E., Mollenhauer, G., Mulitza, S. and Zonneveld, K., 2009, Palynological evidence for climatic and oceanic variability off NW Africa during the late Holocene. Quaternary Research, 72, pp. 188-197, 10.1016/j.yqres.2009.05.003.

Bouimetarhan, I., Groeneveld, J., Dupont, L. and Zonneveld, K., 2013, Low-to high-productivity pattern within Heinrich Stadial 1: Inferences from dinoflagellate cyst records off Senegal. Global and Planetary Change, 106, pp. 64-76, 10.1016/j.gloplacha.2013.03.007.

Bouimetarhan, I., Prange, M., Schefuß, E., Dupont, L., Lippold, J., Mulitza, S. and Zonneveld, K., 2012, Sahel megadrought during Heinrich Stadial 1: Evidence for a three-phase evolution of the low-and mid-level West African wind system. Quaternary Science Reviews, 58, pp. 66-76, 10.1016/j.quascirev.2012.10.015.

Box, E. O., 1981, Predicting physiognomic vegetation types with climate variables. Vegetatio, 45, pp. 127-139, 10.1007/BF00119222.

Bush, M.B., and Rivera R., 1998, Pollen dispersal and representation in a neotropical rain forest. Global Ecology and Biogeography Letters, 7, pp. 379-392, 10.2307/2997685.

Colarco, P. R., Toon, O. B., Reid, J. S., Livingston, J. M., Russell, P. B., Redemann, J. and Campbell, J. R., 2003, Saharan dust transport to the Caribbean during PRIDE: 2. Transport, vertical profiles, and deposition in simulations of in situ and remote sensing observations. Journal of Geophysical Research: Atmospheres, 108, article: 8590.

Denman, K. L., Brasseur, G., Chidthaisong, A., Ciais, P., Cox, P. M., Dickinson, R. E., Hauglustaine, D., Heinze, C., Holland, E., Jacob, D., Lohmann, U., Ramachandran, S., Leite da Silva Dias, P., Wofsy, S.C. and Zhang, X., 2007, Couplings between changes in the climate system and biogeochemistry. In Climate Change 2007: The Physical Science Basis, (Cambridge University Press, Cambridge, United Kingdom and New York, NY, USA), pp. 499-587.

Dupont, L. M., 2006, Late Pliocene vegetation and climate in Namibia (southern Africa) derived from palynology of ODP Site 1082. Geochemistry, Geophysics, Geosystems, 7, 10.1029/2005GC001208, article: Q05007.

Dupont, L.M., 2011, Orbital scale vegetation change in Africa. Quaternary Science Reviews, 30, pp. 3589-3602, 10.1016/j.quascirev.2011.09.019.

Dupont, L.M., 1999, Pollen and spores in marine sediments from the east Atlantic-A view from the ocean into the African Continent. In Use of Proxies in Paleoceanography, edited by Fischer, G. and Wefer, G. (Springer, Berlin, Heidelberg), pp. 523-546.

Dupont, L.M., 2009, The Congo deep-sea fan as an archive of Quaternary change in Africa and the eastern tropical South Atlantic (A review). In External Controls on Deep-Water Depositional Systems, SEPM Society for Sedimentary, Volume 92, edited by Kneller, B., Martinsen, O.J. and McCaffrey, B. (McLean, Va: SEPM Society for Sedimentary Geology), pp. 79-87.

Dupont, L. M. and Agwu, C. O., 1991, Environmental control of pollen grain distribution patterns in the Gulf of Guinea and offshore NW-Africa. Geologische Rundschau, 80, pp. 567-589, 10.1007/BF01803687.

Dupont, L.M. and Kuhlmann, H., 2017, Glacial-interglacial vegetation change in the Zambezi catchment. Quaternary Science Reviews, 155, pp. 127-135, 10.1016/j.quascirev.2016.11.019.

Dupont, L.M. and Schefuß, E., 2018, The roles of fire in Holocene ecosystem changes of West Africa. Earth and Planetary Science Letters, 481, pp. 255-263, 10.1016/j.epsl.2017. 10.049 . 
Dupont, L.M. and Weinelt, M., 1996, Vegetation history of the savanna corridor between the Guinean and the Congolian rain forest during the last 150,000 years. Vegetation History and Archaeobotany, 5, pp. 273-292, 10.1007/BF00195296.

Dupont, L. M. and Wyputta, U., 2003, Reconstructing pathways of aeolian pollen transport to the marine sediments along the coastline of SW Africa. Quaternary Science Reviews, 22, pp. 157-174, 10.1016/S0277-3791(02)00032-X.

Dupont, L. M., Behling, H. and Kim, J. H., 2008, Thirty thousand years of vegetation development and climate change in Angola (Ocean Drilling Program Site 1078). Climate of the Past, 4, pp. 107-124, 10.5194/cp-4-107-2008.

Dupont, L. M., Behling, H., Jahns, S., Marret, F. and Kim, J. H., 2007, Variability in glacial and Holocene marine pollen records offshore from west southern Africa. Vegetation History and Archaeobotany, 16, pp. 87-100, 10.1007/s00334-006-0080-8.

Dupont, L. M., Beug, H. J., Stalling, H. and Tiedemann, R., 1989, First palynological results from Site 658 at $21^{\circ} \mathrm{N}$ off Northwest Africa: Pollen as climate indicators. Proceedings of Ocean Drilling Program Scientific Results, 108, pp. 93-112.

Dupont, L. M., Caley, T., Kim, J. H., Castañeda, I., Malaizé, B. and Giraudeau, J., 2011, Glacialinterglacial vegetation dynamics in South Eastern Africa coupled to sea surface temperature variations in the Western Indian Ocean. Climate of the Past, 7, pp. 1209-1224, 10.5194/cp-71209-2011.

Dupont, L. M., Donner, B., Schneider, R. and Wefer, G., 2001, Mid-Pleistocene environmental change in tropical Africa began as early as $1.05 \mathrm{Ma}$. Geology, 29, pp. 195-198, 10.1130/00917613(2001)029\#amp;lt;0195:MPECIT\#amp;gt;2.0.CO;2.

Dupont, L. M., Marret, F. and Winn, K., 1998, Land-sea correlation by means of terrestrial and marine palynomorphs from the equatorial East Atlantic: Phasing of SE trade winds and the oceanic productivity. Palaeogeography, Palaeoclimatology, Palaeoecology, 142, pp. 51-84, 10.1016/S0031-0182(97)00146-6.

Dupont, L. M., Rommerskirchen, F., Mollenhauer, G. and Schefuß, E., 2013, Miocene to Pliocene changes in South African hydrology and vegetation in relation to the expansion of C4 plants. Earth and Planetary Science Letters, 375, pp. 408-417, 10.1016/j.epsl.2013. 06.005 .

Dupont, L. M., Caley, T. and Castañeda, I. S., 2019, Effects of atmospheric $\mathrm{CO}_{2}$ variability of the past $800 \mathrm{kyr}$ on the biomes of southeast Africa. Climate of the Past, 15, pp. 1083-1097, 10.5194/cp-15-1083-2019.

Fersi, W., Lézine, A.-M. and Bassinot, F., 2016, Hydro-climate changes over southwestern Arabia and the Horn of Africa during the last glacial-interglacial transition: A pollen record from the Gulf of Aden. Review of Palaeobotany and Palynology, 233, pp. 176-185, 10.1016/j.revpalbo.2016.04.002.

Fischer, G., Karakas, G., Blaas, M., Ratmeyer, V., Nowald, N., Schlitzer, R. and Wefer, G., 2009, Mineral ballast and particle settling rates in the coastal upwelling system off NW Africa and the South Atlantic. International Journal of Earth Sciences, 98, pp. 281-298, 10.1007/s00531007-0234-7.

Gajewski, K., 1993, The role of paleoecology in the study of global climatic change. Review of Palaeobotany and Palynology, 79, pp. 141-151, 10.1016/0034-6667(93)90044-U.

Gosling, W.D., and Holden, P.B., 2011, Precessional forcing of tropical vegetation carbon storage. Journal of Quaternary Science, 26, pp. 463-467, 10.1002/jqs.1514.

Hessler, I., Dupont, L., Handiani, D., Paul, A., Merkel, U. and Wefer, G., 2012, Masked millennial-scale climate variations in South West Africa during the last glaciation. Climate of the Past, 8, pp. 841-853, 10.5194/cp-8-841-2012.

Heusser, L. E. and Morley, J. J., 1985, Pollen and radiolarian records from deep-sea core RC14103: climatic reconstructions of Northeast Japan and Northwest Pacific for the last 90,000 years. Quaternary Research, 24, pp. 60-72, 10.1016/0033-5894(85)90083-3. 
Heusser, L.E. and Shackleton, N.J., 1979, Direct marine-continental correlation: 150,000-year oxygen isotope-pollen record from the North Pacific. Science, 204, pp. 837-839.

Hötzel, S., Dupont, L. M. and Wefer, G., 2015, Miocene-Pliocene vegetation change in southwestern Africa (ODP Site 1081, offshore Namibia). Palaeogeography, Palaeoclimatology, Palaeoecology, 423, pp. 102-108, 10.1016/j.palaeo.2015.02.002.

Holdridge, L. R., 1947, Determination of world plant formations from simple climatic data. Science, 105, pp. 367-368, 10.1126/science.105.2727.367.

Hooghiemstra, H., 1988, Palynological records from northwest African marine sediments: a general outline of the interpretation of the pollen signal. Philosophical Transactions of the Royal Society of London. B,Biological Sciences, 318, pp. 431-449.

Hooghiemstra, H. and Agwu, C. O., 1988, Changes in the vegetation and trade winds in equatorial northwest Africa 140,000-70,000 yr BP as deduced from two marine pollen records. Palaeogeography, Palaeoclimatology, Palaeoecology, 66, pp. 173-213, 10.1016/00310182(88)90199-X.

Hooghiemstra, H., Agwu, C. O. C. and Beug, H. J., 1986, Pollen and spore distribution in recent marine sediments: a record of NW-African seasonal wind patterns and vegetation belts. Meteor Forschungsergebnisse, Deutsche Forschungsgemeinschaft, Reihe C Geologie und Geophysik, Gebrüder Bornträger, 40, pp. 87-135.

Hooghiemstra, H., Bechler, A. and Beug, H. J., 1987, Isopollen maps for 18,000 years BP of the Atlantic offshore of northwest Africa: Evidence for paleowind circulation. Paleoceanography, 2, pp. 561-582, 10.1029/PA002i006p00561.

Hooghiemstra, H., Lézine, A.-M., Leroy, S. A., Dupont, L. and Marret, F., 2006, Late Quaternary palynology in marine sediments: a synthesis of the understanding of pollen distribution patterns in the NW African setting. Quaternary International, 148, pp. 29-44, 10.1016/j.quaint.2005.11.005.

Hooghiemstra, H., Stalling, H., Agwu, C. O. and Dupont, L. M., 1992, Vegetational and climatic changes at the northern fringe of the Sahara 250,000-5000 years BP: evidence from 4 marine pollen records located between Portugal and the Canary Islands. Review of Palaeobotany and Palynology, 74, pp. 1-53, 10.1016/0034-6667(92)90137-6.

Hughen, K. A., Baillie, M. G., Bard, E., Beck, J. W., Bertrand, C. J., Blackwell, P. G. and Edwards, R. L., 2004, Marine04 marine radiocarbon age calibration, 0-26 cal kyr BP. Radiocarbon, 46, pp. 1059-1086, 10.1017/S0033822200033002.

Huybers, P., 2011, Combined obliquity and precession pacing of Late Pleistocene deglaciations. Nature, 480, pp. 229-232, 10.1038/nature10626.

Jahns, S., 1996, Vegetation history and climate changes in West Equatorial Africa during the Late Pleistocene and Holocene, based on a marine pollen diagram from the Congo fan. Vegetation History and Archaeobotany, 5, pp. 207-213, 10.1007/BF00217498.

Jahns, S., Hüls, M. and Sarnthein, M., 1998, Vegetation and climate history of west equatorial Africa based on a marine pollen record off Liberia (site GIK 16776) covering the last 400,000 years. Review of Palaeobotany and Palynology, 102, pp. 277-288, 10.1016/S0034-6667(98)80010-9.

Jolly, D., Prentice, I. C., Bonnefille, R., Ballouche, A., Bengo, M., Brenac, P. and Edorh, T., 1998, Biome reconstruction from pollen and plant macrofossil data for Africa and the Arabian peninsula at 0 and 6000 years. Journal of Biogeography, 25, pp. 1007-1027, 10.1046/j.13652699.1998.00238.x.

Julier, A.C.M., Jardine, P.E., Adu-Bredu, S., Coe, A.L., Duah-Gyamfi, A., Fraser, W.T., Lomax, B.H., Malhi, Y., Moore, S., Owusu-Afriyie, K. and Gosling, W.D., 2018, The modern pollenvegetation relationships of a tropical forest-savannah mosaic landscape, Ghana, West Africa. Palynology, 42, pp. 324-338, 10.1080/01916122.2017.1356392.

Le Houérou, H.N., Evenari, M. and Goodall, D.W., 1986, The desert and arid zones of Northern Africa. Ecosystems of the World, 12, pp. 101-147. 
Lee, S. Y. and Poulsen, C. J., 2005, Tropical Pacific climate response to obliquity forcing in the Pleistocene. Paleoceanography, 20, article: PA4010, 10.1029/2005PA001161.

Leroy, SAG., Dupont, LM., 1994, Development of vegetation and continental aridity in northwestern Africa during the Late Pliocene: the pollen record of ODP 658. Palaeogeography, Palaeoclimatology, Palaeoecology, 109, pp. 295-316, 10.1016/0031-0182(94)90181-3.

Lézine, A.-M., 1991, West African paleoclimates during the last climatic cycle inferred from an Atlantic deep-sea pollen record. Quaternary Research, 35, pp. 456-463, 10.1016/00335894(91)90058-D.

Lézine, A.-M. and Cazet, J.P., 2005, High-resolution pollen record from core KW31, Gulf of Guinea, documents the history of the lowland forests of West Equatorial Africa since 40,000 yr ago. Quaternary Research, 64, pp. 432-443, 10.1016/j.yqres.2005.08.007.

Lézine, A.-M. and Hooghiemstra, H., 1990, Land-sea comparison during the last glacialinterglacial transition: Pollen records from west tropical Africa. Palaeogeography, Palaeoecology, Palaeoclimatology, 79, pp. 313-331, 10.1016/0031-0182(90)90025-3.

Lézine, A.-M. and Vergnaud-Grazzini, C., 1993, Evidence of forest extension in West Africa since 22,000 BP: A pollen record from the eastern tropical Atlantic. Quaternary Science Reviews, 12, pp. 203-210, 10.1016/0277-3791(93)90054-P.

Lézine, A.-M., Lemonnier, K., Waller, M.P., Bouimetarhan, I., Dupont, L. and APD contributors, this volume, Changes in the West African landscape at the end of the African Humid Period. Palaeoecology of Africa, 35, chapter: 6, 10.1201/9781003162766-6.

Lézine, A.-M., Leroux, M., Turon, J.L., Buchet, G. and Tastet, J.P., 1995, Transport pollinique et circulation atmospherique au large de l'Afrique tropicale occidentale au cours de la derniere deglaciation. Bulletin de la Société Géologique de France, 166, pp. 247-257.

Lézine, A.-M., Tastet, J.P. and Leroux, M., 1994, Evidence of atmospheric paleocirculation over the Gulf of Guinea since the Last Glacial Maximum. Quaternary Research, 41, pp. 390-395, 10.1006/qres.1994.1043.

Marret, F., 1994, Evolution paléoclimatique et paléohydrologique de l'Atlantique est-équatorial et du proche continent au Quaternaire terminal: contribution palynologique, kystes de dinoflagelles, pollen et spores. PhD thesis, University of Bordeaux I, $271 \mathrm{pp}$.

Marret, F., Scourse, J.D., Versteegh, G., Fred Jansen, J.H. and Schneider, R., 2001, Integrated marine and terrestrial evidence for abrupt Congo River palaeodischarge fluctuations during the last deglaciation. Journal of Quaternary Science, 16, pp. 761-766, 10.1002/ jqs. 646 .

Marret, F., Scourse, J., Fred Jansen, J.H. and Schneider, R., 1999, Climate and palaeooceanographic changes in west central Africa during the last deglaciation: palynological investigation. In Comptes Rendus de l'Académie des Sciences. Série 2, Sciences de la Terre et des Planètes, 1, pp. 721-726.

McGregor, H.V., Dupont, L., Stuut, J. B.W. and Kuhlmann, H., 2009, Vegetation change, goats, and religion: A 2000-year history of land use in southern Morocco. Quaternary Science Reviews, 28, pp. 1434-1448, 10.1016/j.quascirev.2009.02.012.

McManus, J.F., François, R., Gherardi, J.-M., Keigwin, L.D. and Brown-Leger, S., 2004, Collapse and rapid resumption of Atlantic meridional circulation linked to deglacial climate changes. Nature, 428, pp. 834-837, 10.1038/nature02494.

Meadows, M.E., Rogers, J., Lee-Thorp, J.A., Bateman, M.D. and Dingle, R.V., 2002, Holocene geochronology of a continental shelf mud belt off southwestern Africa. The Holocene, 12, pp. 59-67, 10.1191/0959683602hl521rp.

Nash, D.J. and Meadows, M.E., 2012, Africa. In Quaternary Environmental Change in the Tropics, edited by Metcalfe, S.E., Nash, D.J., (Wiley-Blackwell, Oxford, UK), pp. 79-150.

Nicholson, S.E., 2000, The nature of rainfall variability over Africa on time scales of decades to millennia. Global and Planetary Change, 26, pp. 137-158, 10.1016/S0921-8181(00) 00040-0. 
Nicholson, S.E. and Grist, J.P., 2003, The seasonal evolution of the atmospheric circulation over West Africa and equatorial Africa. Journal of Climate, 16, pp. 1013-1030, 10.1175/15200442(2003)016\#amp;lt;1013:TSEOTA\#amp;gt;2.0.CO;2.

Pielke, R.A., Avissar, R., Raupach, M., Dolman, A.J., Zeng, X. and Denning, A. S., 1998, Interactions between the atmosphere and terrestrial ecosystems: influence on weather and climate. Global Change Biology, 4, pp. 461-475, 10.1046/j.1365-2486.1998.t01-1-00176.x.

Prospero, J.M. and Nees, R.T., 1986, Impact of the North African drought and El Nino on mineral dust in the Barbados trade winds. Nature, 320, pp. 735-738, 10.1038/320735a0.

Prospero, J.M., Ginoux, P., Torres, O., Nicholson, S.E. and Gill, T.E., 2002, Environmental characterization of global sources of atmospheric soil dust identified with the Nimbus 7 Total Ozone Mapping Spectrometer (TOMS) absorbing aerosol product. Reviews of Geophysics, 40, pp. 1-31, 10.1029/2000RG000095.

Rasmussen, T.L. and Thomsen, E., 2015, Palaeoceanographic development in Storfjorden, Svalbard, during the deglaciation and Holocene: Evidence from benthic foraminiferal records. Boreas, 44, pp. 24-44, 10.1111/bor.12098.

Rasmussen, S.O., Andersen, K.K., Svensson, A.M., Steffensen, J.P., Vinther, B.M., Clausen, H.B., Siggaard-Andersen, M.-L., Johnsen, S.J., Larsen, L.B., Dahl-Jensen, D., Bigler, M., 2006, A new Greenland ice core chronology for the last glacial termination. Journal of Geophysical Research, 111, D06102, 10.1029/2005JD006079.

Raymo, M.E. and Nisancioglu, K.H., 2003, The 41 kyr world: Milankovitch's other unsolved mystery. Paleoceanography, 18, PA1011, 10.1029/2002PA000791.

Rossignol-Strick, M. and Duzer, D., 1979, West African vegetation and climate since 22,500 BP from deep-sea cores palynology. Pollen et Spores, 21, pp. 105-134.

Sánchez Goñi, M.F., Eynaud, F., Turon, J.L. and Shackleton, N.J., 1999, High resolution palynological record off the Iberian margin: Direct land-sea correlation for the Last Interglacial complex. Earth and Planetary Science Letters, 171, pp. 123-137, 10.1016/S0012821X(99)00141-7.

Scourse, J., Marret, F., Versteegh, G.J., Jansen, J.F., Schefuss, E. and van der Plicht, J., 2005, High-resolution last deglaciation record from the Congo fan reveals significance of mangrove pollen and biomarkers as indicators of shelf transgression. Quaternary Research, 64, pp. 57-69, 10.1016/j.yqres.2005.03.002.

Shannon, L.V., 1985, The Benguela ecosystem. I: Evolution of the Benguela physical features and processes. Oceanography and Marine Biology, 23, pp. 105-182.

Shannon, L.V. and Nelson, G., 1996, The Benguela: Large-scale features and processes and system variability. In The South Atlantic, edited by Wefer, G.W.H., Berger and Webb, D.J. (Springer, Berlin, Heidelberg), pp. 163-210.

Shi, N. and Dupont, L.M., 1997, Vegetation and climatic history of southwest Africa: a marine palynological record of the last 300,000 years. Vegetation History and Archaeobotany, 6, pp. 117-131, 10.1007/BF01261959.

Shi, N., Dupont, L.M., Beug, H. J. and Schneider, R., 1998, Vegetation and climate changes during the last 21000 years in SW Africa based on a marine pollen record. Vegetation History and Archaeobotany, 7, pp. 127-140, 10.1007/BF01374001.

Shi, N., Schneider, R., Beug, H. J. and Dupont, L.M., 2001, Southeast trade wind variations during the last 135 kyr: evidence from pollen spectra in eastern South Atlantic sediments. Earth and Planetary Science Letters, 187, pp. 311-321, 10.1016/S0012-821X(01) 00267-9.

Stuut, J.B., Zabel, M., Ratmeyer, V., Helmke, P., Schefuß, E., Lavik, G. and Schneider, R., 2005, Provenance of present-day eolian dust collected off NW Africa. Journal of Geophysical Research: Atmospheres, 110, D04202, 10.1029/2004JD005161.

Tyson, P.D., 1986, Climatic Change and Variability in Southern Africa, (Cape Town: Oxford University Press). 
Tyson, P.D. and Preston-Whyte, R.A., 2000, The Weather and Climate of South Africa, (Cape Town: Oxford University Press).

Vallé, F., Westerhold, T. and Dupont, L.M., 2017, Orbital-driven environmental changes recorded at ODP Site 959 (eastern equatorial Atlantic) from the Late Miocene to the Early Pleistocene. International Journal of Earth Sciences, 106, pp. 1161-1174, 10.1007/s00531-016-1350-z.

Vincens, A., Dubois, M.A., Guillet, B., Achoundong, G., Buchet, G., Kamgang Kabeyene Beyala, V., de Namur, C. and Riera, B., 2000, Pollen-rain-vegetation relationships along a forest-savanna transect in southeastern Cameroon. Review of Palaeobotany and Palynology, 110, pp. 191-208, 10.1016/S0034-6667(00)00009-9.

Watrin, J., Lézine, A.-M., Gajewski, K. and Vincens, A., 2007, Pollen-plant-climate relationships in sub-Saharan Africa. Journal of Biogeography, 34, pp. 489-499, 10.1111/j.13652699.2006.01626.x.

Webb, T.I., 1986, Is vegetation in equilibrium with climate? How to interpret Late-Quaternary pollen data. Vegetatio, 67, pp. 75-91, 10.1007/BF00037359.

White, F., 1983, The vegetation of Africa, In Natural Resources Research,Vol.20, (UNESCO, Paris), $384 \mathrm{pp}$.

Woodward, F.I. and McKee, I.F., 1991, Vegetation and climate. Environment International, 17, pp. 535-546, 10.1016/0160-4120(91)90166-N.

Woodward, F.I. and Williams, B.G., 1987, Climate and plant distribution at global and local scales, Vegetatio, 69, pp. 189-197, 10.1007/BF00038700.

Wright, J.W., 1952, Pollen dispersion of some forest trees, In Research paper 46 (Upper Darby, US Department of Agriculture Service-Forest Service Northeastern Forest, Experiment Station), pp. 1-45.

Zhao, X., Dupont, L., Cheddadi, R., Kölling, M., Reddad, H., Groeneveld, J. and Bouimetarhan, I., 2019, Recent climatic and anthropogenic impacts on endemic species in southwestern Morocco. Quaternary Science Reviews, 221, pp. 1-15, 10.1016/j.quascirev.2019.105889.

Zhao X., Dupont L., Meadows, M.E. and Wefer, G., 2016, Pollen distribution in the marine surface sediments of the mudbelt along the west coast of South Africa. Quaternary International, 404, pp. 44-56, 10.1016/j.quaint.2015.09.032. 